\title{
Calciphylaxis and Martorell Hypertensive Ischemic Leg Ulcer: Same Pattern - One Pathophysiology
}

\author{
Jürg Hafner \\ Department of Dermatology, University Hospital of Zurich, Zurich, Switzerland
}

\section{Key Words \\ Calciphylaxis - Martorell hypertensive ischemic leg ulcer . Eutrophication - Arteriolosclerosis - Medial calcification . Fetuin A - Sodium thiosulfate - Debridement - Skin graft}

\begin{abstract}
This review presents a closer look at four diseases which are probably closely related to one another pathophysiologically: (a) calciphylaxis (distal pattern); (b) calciphylaxis (proximal pattern); (c) Martorell hypertensive ischemic leg ulcer; (d) calciphylaxis with normal renal and parathyroid function (synonym: eutrophication). The four diseases have largely the same risk factors: (1) arterial hypertension, (2) diabetes mellitus (types 1 and 2), (3) secondary or tertiary hyperparathyroidism (in end-stage kidney disease) and (4) oral anticoagulation with vitamin $\mathrm{K}$ antagonists. They share the same clinical patterns: necrotizing livedo, skin infarctions at typical locations and acral gangrene in calciphylaxis. They also share the same histopathology: ischemic subcutaneous arteriolosclerosis and small-artery disease and 'miniaturizing' Mönckeberg medial calcinosis. The treatment concept for the acute phase of the diseases is also broadly similar. In addition to an optimized control of the cardiovascular risk factors, a proactive wound approach (necrosectomy, negative pressure wound treatment with vacuum dressings, and early skin grafts supported by systemic antibiotic therapy) leads
\end{abstract}

most rapidly and effectively to a reduction of the initially severe wound pain, and finally to complete healing of the wound. Oral anticoagulation with vitamin $\mathrm{K}$ antagonists should be stopped. In extensive cases, the use of intravenous sodium thiosulfate is recommended. All four diagnoses are little known in the medical schools of most countries. The need to improve familiarity with these four closely related disorders is therefore great. In particular, the risk of confusion with pyoderma gangrenosum is a major diagnostic problem which can lead to false and even damaging treatment.

(c) 2016 S. Karger AG, Basel

\section{Introduction}

Martorell hypertensive ischemic leg ulcer (HYTILU) and calciphylaxis (synonym: calcific uremic arteriolopathy) share a common clinical appearance and pathophysiology: skin infarction as a result of subcutaneous stenotic arteriolosclerosis, accompanied by medial calcinosis. The characteristic vascular pathology which unifies the two entities can be detected on skin biopsies if the appropriate sampling technique is used. The following review summarizes the characteristic clinical and histopathological features, the pathophysiological understanding and a therapeutic concept for these two closely related diseases.

\section{KARGER}

E-Mail karger@karger.com

www.karger.com/drm
(C) 2016 S. Karger AG, Basel

$1018-8665 / 16 / 2325-0523 \$ 39.50 / 0$
Jürg Hafner

Department of Dermatology, University Hospital of Zurich

Rämistrasse 100

CH-8091 Zurich (Switzerland)

E-Mail juerg.hafner@usz.ch 
Fig. 1. Identical histopathology patterns: 'classical' calciphylaxis in end-stage kidney disease or after successful kidney transplantation and 'calciphylaxis' in normal renal and parathyroid function show the same histologic features at the level of subcutaneous arterioles: ischemic arteriolosclerosis, medial calcification, and intimal hyperplasia; the narrow lumen can be thrombosed.

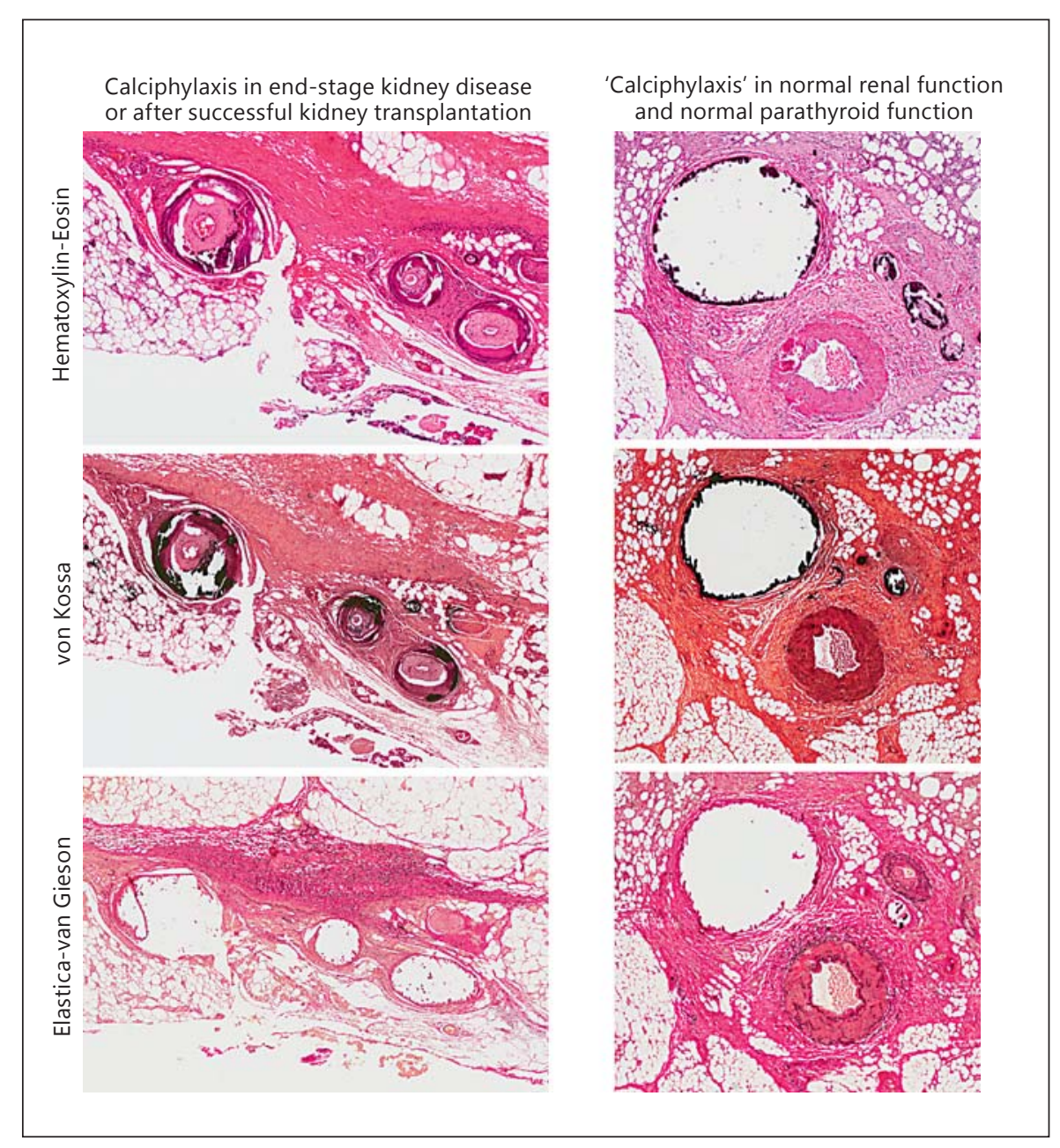

\section{History of Calciphylaxis}

Patients with end-stage kidney disease and those after successful kidney transplantation can develop a devastating syndrome of multiple skin infarctions and/or acral gangrene [1-4]. On histopathology, advanced atherosclerosis of small arteries (finger, toes, penis) and/or subcutaneous arterioles is regularly found, characterized by a medial calcinosis and stenosis either due to thickening of the vessel wall (hyperplasia of the smooth muscle layer, the 'muscularis') and/or intimal hyperplasia (fig. 1). Many patients with calciphylaxis also exhibit soft tissue calcifications, e.g. of the subcutaneous septae, but the kidneys, lungs or stomach may also be affected, particularly if they suffer from untreated secondary hyperparathyroidism. Selye [5] was a pathophysiologist who conducted animal experiments on the mechanism of metastatic calcification. After exposing animals to very high doses of vitamin $\mathrm{D}$ or parathyroid hormone, he injected iron salts or pro- teins intravenously/intraperitoneally and was able to demonstrate massive metastatic calcification of the solid organs and peritoneum. He did not demonstrate atherosclerosis with medial calcification, currently regarded as the basic pathophysiology of skin infarction and acral gangrene in nephrology patients.

Selye developed a unique terminology for his experiment and called the preparation stage with the application of very high doses of vitamin D or parathyroid hormone 'sensitization' and the moment of intravenous/ intraperitoneal application of iron salts or proteins 'challenge', and the whole pathophysiological concept 'calciphylaxis' in reference to assumed parallels with allergy and anaphylaxis. From a more modern point of view, Selye's experiments are unsuited to explain what nephrologists renamed 'uremic calcific arteriolopathy' [1, 2], a term which has not yet replaced the more customary misnomer 'calciphylaxis' still in general use. In 1995, we 
suggested the term 'uremic small-artery disease with medial calcification and intimal hyperplasia' [6] to overcome Selye's concept of 'calciphylaxis'. Today, after 20 further years of reflection and the 'rediscovery' of Martorell hypertensive ischemic leg ulcer [7], we believe that vascular medicine and all other involved specialties should focus on the pathophysiology of arterioles and small arteries under long-term exposure to hypertension and/or diabetes. This vascular segment, which lies between the very well-explored macroatherosclerosis of the most vital vascular territories and the well-characterized microangiopathies of the capillary bed, is not yet adequately investigated and understood.

\section{History of Martorell HYTILU}

A group of Dutch and Belgian/Flemish authors have concisely summarized the history of Martorell HYTILU [8]. In 1940, Haxthausen was the first to publish on leg ulcers in hypertension, followed by Hines 1 year later (1941). The underlying histopathological changes of the subcutaneous arterioles were almost simultaneously described by Martorell, Farber and Hines. As a young physician, Martorell visited the Mayo Clinic in Rochester and hospitals in Chicago and New York. In 1943 he had a vocation to lead the Istituto Policlinico in Barcelona, an outpatient department devoted to vascular diseases [9]. It is possible that Hines discussed his observation of leg ulcers in hypertensive patients with the Spanish visiting physician. In 1945, Martorell described las ulceras supramaleolares por arteriolitis de las grandes hipertensas in 4 obese women [10]. In 1946-1947, Farber and Hines stressed the link between the striking histopathology of the underlying arterioles showing distinctive wall thickening resulting in a narrow lumen and coined the term still in use today of 'hypertensive ischemic leg ulcer' $[11,12]$. It was Schnier et al. [13], who described the typical location on the laterodorsal leg, and several authors, among them Bertranou et al. [14], Lazareth and Priollet [15] and Dagregorio and Guillet [16], recommended early debridement and skin grafting to enhance wound healing and effectively alleviate pain. In their comprehensive review from 2010, Vuerstaek et al. [8] collected 889 cases published in 53 articles and theses. Some authors argue that Martorell HYTILU may in fact be more common than previously acknowledged and that many physicians may be totally unaware of the entity. France may be one of the countries with the highest awareness, as reflected by several larger-scale studies. In French, Martorell HYTILU is termed 'angiodermite nécrotique'.

Calciphylaxis and Martorell Leg Ulcer:

Same Pathophysiology
History of Calciphylaxis with Normal Renal and

Parathyroid Function (Synonym: Eutrophication)

'Calciphylaxis in normal renal function' [17] consistently affects morbidly obese people suffering from arterial hypertension and type 2 diabetes as a result of their metabolic syndrome [7]. The disease is characterized by the rapid appearance of progressive skin infarctions in the regions of the inner thigh, fatty abdominal apron, breasts or outer upper arms - i.e. in places where fatty tissue is particularly thick in morbid obesity. Stenotic, ischemic subcutaneous arteriolic sclerosis is found in skin biopsies. Histologically, the disease process of calciphylaxis is not to be differentiated from Martorell HYTILU. The pathophysiology of 'calciphylaxis in normal renal function' is to this day unclear. In 2010, we presented the hypothesis that 'calciphylaxis with normal renal and parathyroid function' and Martorell HYTILU represent the proximal and distal variants of the same disease, analogous to the proximal and distal calciphylaxis of patients with kidney damage [7].

Ramsey-Stewart [18] described the entity as 'eutrophication', and Kalajian et al. [17] reported on a series of patients under the more descriptive term 'calciphylaxis with normal renal and parathyroid function'. Hackett et al. [19] reported successful treatment with sodium thiosulfate, shortly after the introduction of this modality, for the treatment of severe cases of classical calciphylaxis.

$\alpha_{2}$-Heremans-Schmid Glycoprotein (Synonym: Fetuin

A or Matrix Protein GLA) and Potential Side Effects

of Vitamin K Antagonists in Calciphylaxis and

Martorell HYTILU

In the earlier literature on calciphylaxis, nephrologists observed and suspected that oral anticoagulation with vitamin $\mathrm{K}$ antagonists may exacerbate the condition [1]. With the detection of $\alpha_{2}$-Heremans-Schmid glycoprotein (AHSG) in the 1990s, this hypothesis was proven correct. AHSG is - comparable to albumin - a carrier protein capable of binding to insoluble calcium phosphate, and hence a potent inhibitor of pathological calcification [20]. AHSG requires vitamin $\mathrm{K}$-dependent $\gamma$-carboxylation to become active - like the vitamin K-dependent clotting factors. Nephrologists therefore stop treatment with vitamin $\mathrm{K}$ antagonists in anticoagulated calciphylaxis patients $[4,21]$ and switch to low-molecular-weight heparins. The use of oral direct factor X inhibitors or thrombin inhibitors is contraindicated in advanced stages of renal insufficiency. 
Sodium Thiosulfate in the Treatment of Extensive

Calciphylaxis and Martorell HYTILU

Sodium thiosulfate is used in photography and metallurgy as binding salt. Nephrologists have introduced sodium thiosulfate to bind calcium in patients with calciphylaxis. Several case series confirm its effectiveness in patients with extensive classical calciphylaxis $[4,22]$ as well as in calciphylaxis with normal renal and parathyroid function [19]. Varying intravenous doses have been reported, the most common dose being between 10 and $25 \mathrm{~g}$ during or after each hemodialysis in adults [23], or 3 times per week in patients with calciphylaxis with normal renal function. In our experience, sodium thiosulfate is well tolerated. The anion gap metabolic acidosis can lead to nausea and vomiting; however, this can be effectively controlled with antiemetic drugs.

Basically however, an elevated calcium $\times$ phosphate product is treated by increasing the frequency of hemodialysis sessions, calcium-free intestinal phosphate binders and the calcimimetic drug cinecalcet $[4,23]$. Vitamin $\mathrm{D}_{3}$ substitution is standard in all patients with chronic venous insufficiency.

\section{Confusing Martorell HYTILU with Pyoderma \\ Gangrenosum Can Be Detrimental}

In 2010, we published a series of case studies on 31 patients in which we highlighted the issue of the misdiagnosis of Martorell ulcers as pyoderma gangrenosum (about $50 \%$ of referred patients) or necrotizing vasculitis (about $16 \%$ of patients) [7].

Treatment of these three disorders, all of which are characterized by severe skin damage and have a similar appearance, goes in diametrically opposed directions:

Patients with pyoderma gangrenosum require highdose systemic immunosuppression, typically with glucocorticoids. At the same time, surgical procedures are contraindicated, as they might exacerbate the wound situation (pathergy phenomenon). In contrast, patients with Martorell HYTILU, calciphylaxis with normal renal function or classical calciphylaxis do not require immunosuppression, but rather a surgical approach in the acute phase (as extensively discussed below). Patients with necrotizing vasculitis typically require systemic immunosuppression in the early stages of the disease, later wound debridement and often skin grafts as well. It is therefore extremely important to clearly differentiate the three disorders. This is possible in almost all cases due to the differences in the symptom patterns, underlying diseases and histology [7].

\section{The Common Clinical Pattern of Calciphylaxis, Martorell HYTILU and Calciphylaxis with Normal Renal and Parathyroid Function (Eutrophication)}

Calciphylaxis is a syndrome of skin infarctions and acral gangrene in patients with chronic renal insufficiency or after successful kidney transplantation. It is differentiated into a distal form (fig. 2a) with a better prognosis (approx. 10\% mortality) and a proximal form (fig. 2b) with a poorer prognosis (approx. 60\% mortality) [1-4]. In the distal form of calciphylaxis, the skin infarctions occur at any site on the legs, predominantly on the laterodorsal lower leg and above the Achilles tendon. Acral gangrene can affect the toes, fingers and the penis. In the proximal form of calciphylaxis, the inner thighs, abdominal fatty apron, breasts and the outer upper arms are most commonly affected. A stenotic, ischemic subcutaneous arteriolosclerosis is found histopathologically. Some of the arterioles demonstrate a 'miniaturized Mönckeberg sclerosis' [6]. Heterotopic calcifications can also be found interstitially in fatty tissue in calciphylaxis.

Martorell HYTILU is characterized by a progressive, extremely painful skin necrosis of the lower leg $[7,8]$, with a marked predisposition for the laterodorsal lower leg or above the Achilles tendon (fig. 2c). This location is highly typical and found in approximately $90 \%$ of affected patients $[7,13]$. The skin infarction begins clinically as a livid, painful area, usually characterized by livedo racemosa, which rapidly becomes necrotic with a progressive, livid margin. Because of the extreme pain and the inflamed, livid wound margin, doctors unfamiliar with the clinical picture often initially diagnose pyoderma gangrenosum or necrotizing vasculitis of the skin. In contrast to pyoderma gangrenosum however, the wound margin is not pustular, and from the beginning the necrosis spreads through all three skin layers right down to the fascia. Notably, patients with Martorell ulcers do not suffer from the typical underlying 'neutrophilic disorders' such as inflammatory bowel disorders (colitis ulcerosa or Crohn's disease), rheumatoid arthritis, or from a hematoproliferative disorder (e.g. myeloid leukemia).

Most patients with Martorell ulcers are over 60 years of age and have had arterial hypertension for many years, usually well controlled. In addition, approximately $60 \%$ of patients with Martorell ulcers have type 2 diabetes mellitus, also generally well controlled [7].

On examination of the arteries in the affected leg, approximately $50 \%$ of patients have 'classic' peripheral arterial occlusive disease, i.e. macroangiopathy of the iliac, superficial femoral, popliteal or lower leg arteries. In the 
Fig. 2. Common clinical patterns: 'classical' calciphylaxis in end-stage kidney disease or after successful kidney transplantation and 'calciphylaxis' in normal renal and parathyroid function share the same clinical features: progressive ischemic livedo with very painful skin infarctions, at the laterodorsal leg or over the Achilles tendon, thighs, upper arms, fatty abdominal apron, and breasts. 'Classical' calciphylaxis can involve fingers, toes, and the penis.

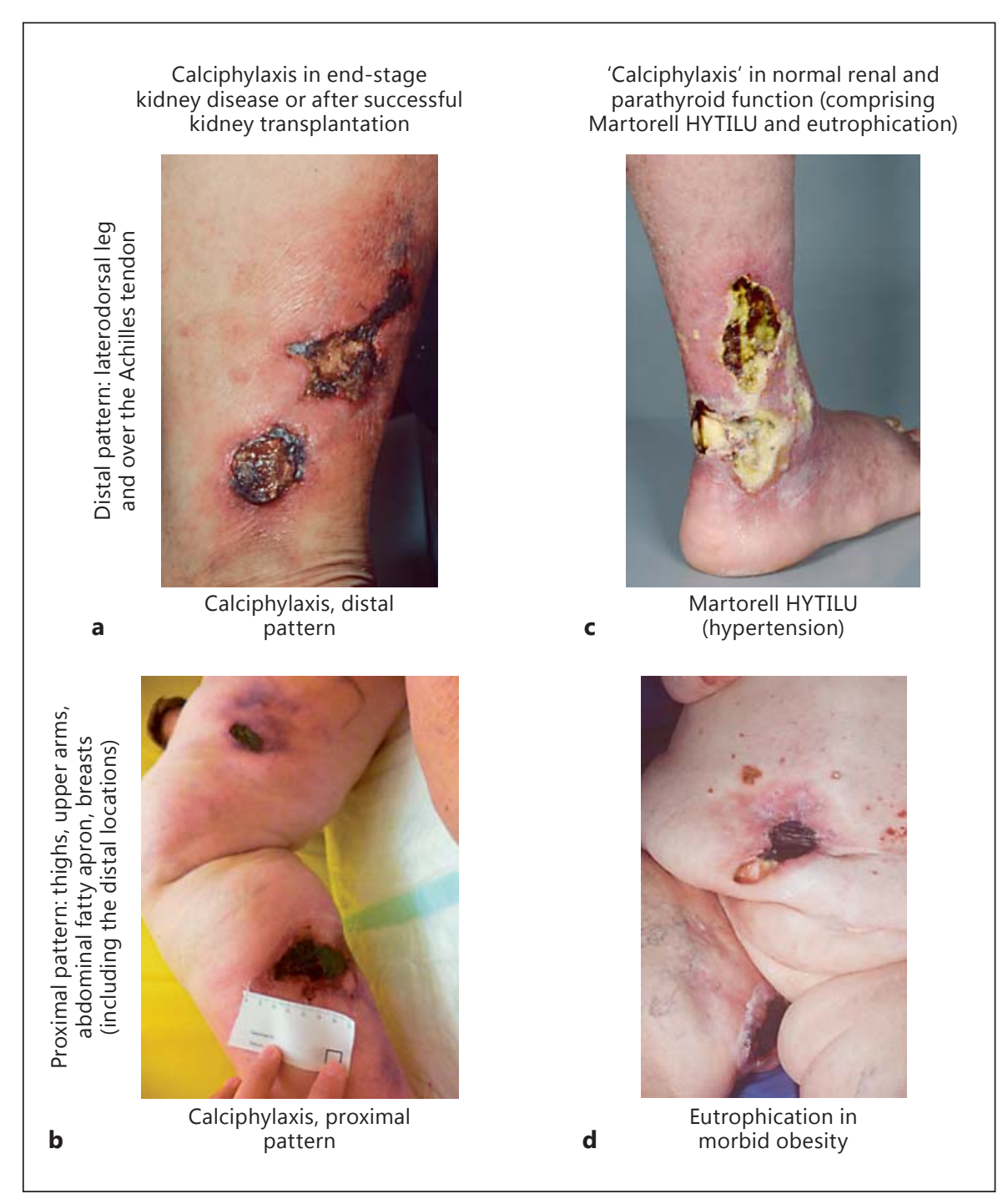

course of this disease, approximately $50 \%$ of patients suffer from a Martorell ulcer 'mirrored' on the opposite leg, generally also in a laterodorsal location, either simultaneously or several months or years later [7].

Calciphylaxis with normal renal and parathyroid function (synonym: eutrophication) cannot be clinically and histopathologically distinguished from the proximal pattern of classical calciphylaxis - with the difference that these patients have normal kidney function [17]. The skin of the inner thighs, abdominal fatty apron, breasts and the outer upper arms develops severe livedo which can rapidly progress to become extremely painful skin infarctions (fig. 2d). All patients with this type of 'calciphylaxis' suffer from morbid obesity - and in our own experience always have primary arterial hypertension and diabetes mellitus type 2 [7].

\section{The Common Histopathological Pattern of Calciphylaxis, Martorell HYTILU and Calciphylaxis with Normal Renal and Parathyroid Function (Eutrophication)}

The definitive diagnosis of Martorell HYTILU can be made via spindle biopsy. The sample must be taken through both healthy and affected tissues and be of sufficient length and depth, albeit narrow. Such spindle biopsies usually measure $6 \mathrm{~cm}$ in length, $6 \mathrm{~mm}$ in width and 6-40 $\mathrm{mm}$ in depth and extend to the fascia of the lower leg or at other locations deep into the subcutis. The biopsy site can be simply closed with reabsorbent suture material, and the iatrogenic damage for the patient is minimal. The complete length of the sample must be sectioned and embed- 


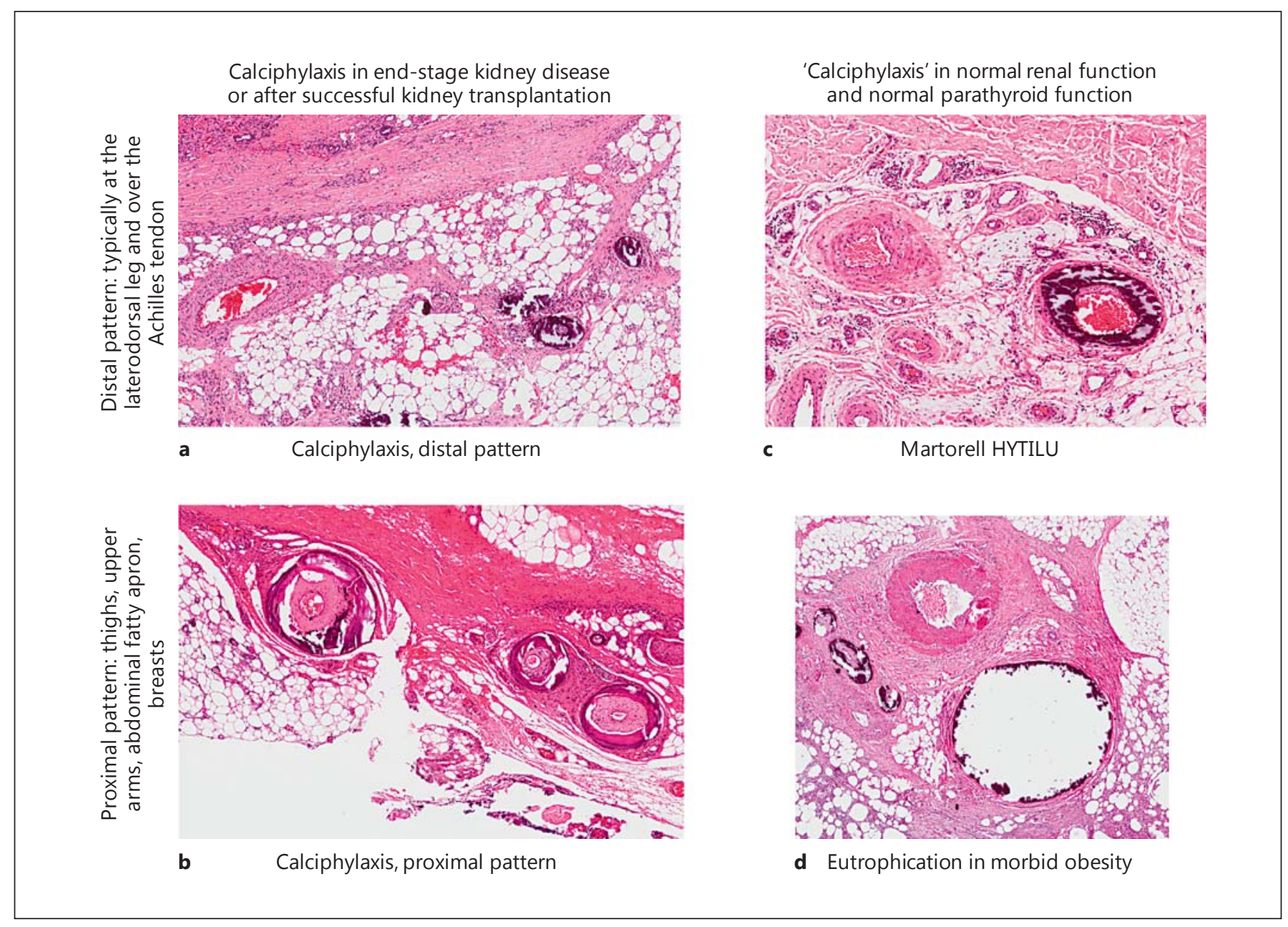

Fig. 3. Common histological pattern (for details, see fig. 1).

ded lengthways. In this way, the histopathology provides a 'profile' of epidermis, dermis and subcutis, and it is highly probable that the relevant pathological arterioles will be found in the subcutis of this longitudinal section of skin and wound tissue [7]. Obligatory findings for the diagnosis are arterioles with extremely thickened walls, with the resultant severely constricted lumens. In one section of the arterioles cell-rich or cell-poor thrombi are to be found, whereby it is not possible to determine whether these arterial thrombi developed shortly before or as a result of the skin infarction. Medial calcinosis, corresponding to 'miniaturized Mönckeberg sclerosis', can be found in over 50\% of histology slides [7]. Calciphylaxis in its distal and proximal form, Martorell HYTILU and calciphylaxis with normal renal and parathyroid function (eutrophication) all exhibit the same histological pattern (fig. 3a-d): ischemic skin infarction with subcutaneous arteriolosclerosis. The arterioles show massive thickening of the vessel wall (hyperplasia of the muscularis) leaving a narrow lumen that is often thrombosed. In $70 \%$ of histologies, a 'miniaturized Mönckeberg medial calcinosis' can be found, which is often accompanied by a pronounced intimal hyperplasia at the cost of a narrow lumen.

\section{The Common Pathophysiology of Calciphylaxis, Martorell HYTILU and Calciphylaxis in Normal Renal and Parathyroid Function (Eutrophication)}

\section{The Classical Hypothesis: Metastatic Calcification (Raised $\mathrm{Ca} \times \mathrm{PO}_{4}$ Product)}

The classical pathophysiological explanation would give hyperphosphatemia with the raised calcium $\times$ phosphate product of patients with chronic renal insufficiency 
as the cause of the calciphylaxis $[1-3,5]$. The lack of biologically active vitamin $\mathrm{D}_{3}$ (calcitriol; 1,25-dihydroxycholecalciferol) leads to calcium deficiency, which is compensated by a secondary hyperparathyroidism. Calcium is mobilized from the bones to ward off the threat of hypocalcemia. The phosphate simultaneously released from the bones is, however, renally retained. In the classical explanation, calciphylaxis is therefore understood as metastatic calcinosis $[1-3,5]$. The recently published data from the large German nationwide calciphylaxis registry [4], however, give little support for this single-track model. Hyperparathyroidism cannot sufficiently explain the cause of calciphylaxis.

\section{The Unifying Hypothesis: Four Risk Factors of}

\section{Ischemic Arteriolosclerosis}

In 2010, we presented the hypothesis that four risk factors can lead to ischemic arteriolosclerosis [7]: (1) hypertension is the driving risk factor in the development of calciphylaxis, Martorell HYTILU and calciphylaxis with normal renal and parathyroid function; many patients with chronic renal insufficiency have long-standing primary arterial hypertension, and the majority develops renal hypertension; (2) diabetes mellitus (types 1 and 2) is the most common cause of end-stage kidney disease; thus, the second most common risk factor for stenotic, ischemic subcutaneous arteriolosclerosis is also present in a proportion of patients with calciphylaxis; (3) secondary hyperparathyroidism plays an additional role as a third risk factor for classical calciphylaxis in patients with end-stage kidney disease and also in those after successful transplantation; (4) oral anticoagulation with vitamin K antagonists inhibits AHSG, an important protective factor against pathological calcification.

\section{Is Arteriolosclerosis Under- or Overdiagnosed?}

The proportion of Martorell HYTILU diagnosed by wound experts worldwide differs widely amongst all etiologies of leg ulcers [23]. Working at a tertiary referral center with a focus on Martorell HYTILU raises the risk of overdiagnosis, however. On the other hand, the paucity of information on calciphylaxis and Martorell HYTILU in medical textbooks and the medical literature in general leads to a lack of awareness of physicians for these entities and thus to underdiagnosis of all four of the above entities linked to ischemic arteriolosclerosis. There is, however, a plausible reason why Martorell HYTILU may really increase. Morbidity and mortality from coronary heart disease and stroke are declining, essentially as a result of population screening and widely available highly

Calciphylaxis and Martorell Leg Ulcer:

Same Pathophysiology effective antihypertensive medications. This may give rise to a truly increasing incidence of Martorell HYTILU as a late-in-life complication in long-term survivors of primary arterial hypertension.

\section{The Common Treatment Concept of Calciphylaxis, Martorell HYTILU and Calciphylaxis with Normal Renal and Parathyroid Function (Eutrophication)}

Some authors suggest antihypertensive medications as first-line treatment of Martorell HYTILU. However, the arteriolar pathology is not functional but morphologically fixed. For this reason, it is not possible to bring about healing of Martorell HYTILU simply by getting the hypertension (which is usually already treated) under control. Due to the extreme wound pain, and despite their normally adequate antihypertensive treatment, most patients develop blood pressure spikes which may require an increase in antihypertensive treatment.

Treatment of skin infarctions from ischemic arteriolosclerosis is essentially surgical $[4,6,14-16]$. Numerous work groups have empirically determined and published that patients can be most rapidly and effectively helped when the necrotic tissue is excised and the wound covered early with a skin graft. The fascia of the lower leg at the base of the fresh excision wound is usually suitable for an immediate skin transplant in one step. The subcutaneous fatty tissue at the wound margin, on the other hand, is unsuitable for the direct take of a skin graft. If the receiving wound bed is high in subcutaneous fat and its margins are already slightly damaged, negative pressure wound therapy with a vacuum dressing can be applied for a number of days to increase the chances of the skin graft 'taking'. The majority of patients require a resistance-adjusted systemic antibiotic therapy in this acute surgical treatment phase. If the skin graft has been successful, the typically severe wound pain recedes astonishingly rapidly to a bearable level within approximately 1-2 days. The grafted skin usually 'takes' completely in the center, directly onto the fascia of the lower leg, whereas the wound margins usually require longer to heal. The necrotic process often continues at the margins, even after a successful skin graft. It is usually possible to bring about complete healing of the remaining wound over weeks and months of conservative treatment and with good quality of life. Around $30-40 \%$ of patients require 2 and sometimes even 3 skin grafts to stop the necroses and bring about the healing process. If the Achilles tendon is exposed and necrotic, it can be resectioned. The graft is then made onto 


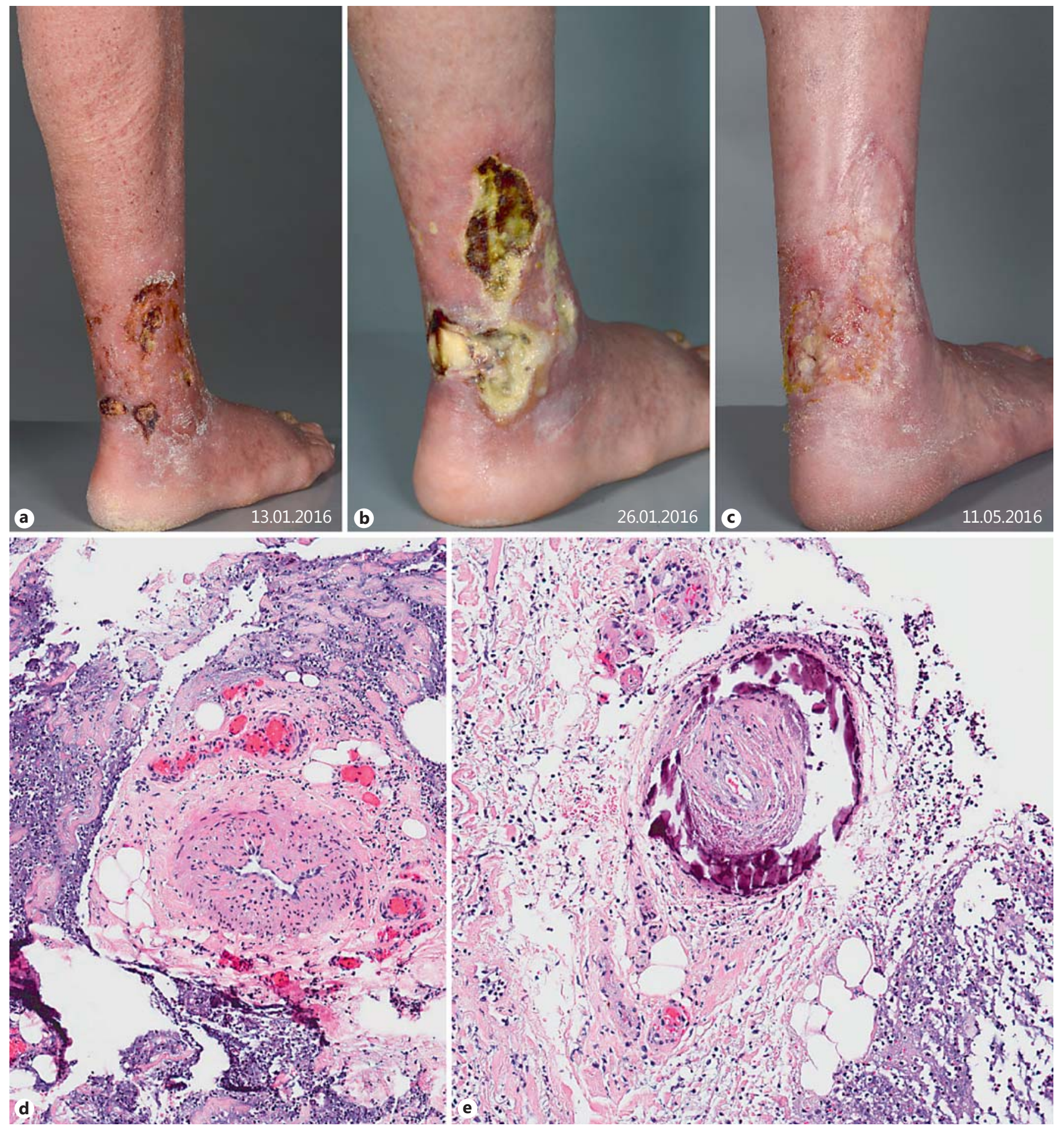

Fig. 4. Martorell HYTILU. a Presentation at first visit. b Rapid exacerbation with extensive skin infarction within 2 weeks. c Treatment: Na thiosulfate plus wound surgery (resection of Achilles tendon, negative pressure wound treatment, split skin graft). d Subcutaneous arteriolosclerosis: hyperplasia of the muscularis at the cost of the vessel lumen causes ischemic skin infarction. e 70\% of histologies exhibit a 'miniaturized Mönckeberg medial calcification' that is often accompanied by intimal hyperplasia (luminal narrowing). 
Table 1. Subcutaneous arteriolosclerosis (synopsis)

\begin{tabular}{|c|c|c|c|}
\hline Martorell HYTILU & $\begin{array}{l}\text { Calciphylaxis with normal renal and } \\
\text { parathyroid function (eutrophication) }\end{array}$ & $\begin{array}{l}\text { Calciphylaxis in chronic renal failure or } \\
\text { renal transplant recipients (distal pattern) }\end{array}$ & $\begin{array}{l}\text { Calciphylaxis in chronic renal failure or renal } \\
\text { transplant recipients (proximal pattern) }\end{array}$ \\
\hline $\begin{array}{l}\text { Cardiovascular risk factors } \\
\text { Arterial hypertension }(100 \%) \\
\text { Diabetes mellitus type } 2(60 \%)\end{array}$ & $\begin{array}{l}\text { Arterial hypertension (100\%) } \\
\text { Diabetes mellitus type } 2(100 \%)\end{array}$ & $\begin{array}{l}\text { Arterial hypertension }(\sim 100 \%) \\
\text { - Essential hypertension } \\
\text { - Renal hypertension } \\
\text { Diabetes mellitus type } 2 \\
\text { Diabetes mellitus type } 1 \\
\text { Secondary/tertiary hyperparathyroidism }\end{array}$ & $\begin{array}{l}\text { Arterial hypertension }(\sim 100 \%) \\
\text { - Essential hypertension } \\
\text { - Renal hypertension } \\
\text { Diabetes mellitus type } 2 \\
\text { Diabetes mellitus type } 1 \\
\text { Secondary/tertiary hyperparathyroidism }\end{array}$ \\
\hline $\begin{array}{l}\text { Clinical syndrome } \\
\text { Skin infarction } \pm \text { livedo } \\
\text { - Laterodorsal leg } \\
\text { - Achilles tendon } \\
\text { - Other locations (rare) }\end{array}$ & $\begin{array}{l}\text { Skin infarction } \pm \text { livedo } \\
\text { - Thighs, inner aspect } \\
\text { - Abdominal fatty apron } \\
\text { - Upper arms (laterodorsal) } \\
\text { - Breasts } \\
\text { Plus } \\
\text { - Distal locations }\end{array}$ & $\begin{array}{l}\text { Skin infarction } \pm \text { livedo } \\
\text { - Laterodorsal leg } \\
\text { - Achilles tendon } \\
\text { - Other locations (rare) } \\
\text { Acral gangrene } \\
\text { - Finger, toes } \\
\text { - Penis }\end{array}$ & $\begin{array}{l}\text { Skin infarction } \pm \text { livedo } \\
\text { - Thighs, inner aspect } \\
\text { - Abdominal fatty apron } \\
\text { - Upper arms (laterodorsal) } \\
\text { - Breasts } \\
\text { Plus } \\
\text { - Distal locations }\end{array}$ \\
\hline $\begin{array}{l}\text { Histopathology } \\
\text { Subcutaneous arteriolosclerosis } \\
\text { - Thick vessel wall } \\
\text { - Narrow vessel lumen } \\
\text { - Arteriolar thrombosis } \\
\text { - Miniaturized Mönckeberg } \\
\text { medial calcinosis }\end{array}$ & $\begin{array}{l}\text { Subcutaneous arteriolosclerosis } \\
\text { - Thick vessel wall } \\
\text { - Narrow vessel lumen } \\
\text { - Arteriolar thrombosis } \\
\text { - Miniaturized Mönckeberg } \\
\text { medial calcinosis }\end{array}$ & $\begin{array}{l}\text { Subcutaneous arteriolosclerosis } \\
\text { - Thick vessel wall } \\
\text { - Narrow vessel lumen } \\
\text { - Arteriolar thrombosis } \\
\text { - Miniaturized Mönckeberg } \\
\text { medial calcinosis }\end{array}$ & $\begin{array}{l}\text { Subcutaneous arteriolosclerosis } \\
\text { - Thick vessel wall } \\
\text { - Narrow vessel lumen } \\
\text { - Arteriolar thrombosis } \\
\text { - Miniaturized Mönckeberg } \\
\text { medial calcinosis }\end{array}$ \\
\hline $\begin{array}{l}\text { Treatment } \\
\text { Control cardiovascular risk factors } \\
\text { Sufficient analgetics as required } \\
\text { Debridement or necrosectomy } \\
\text { In extensive cases: } \\
\text { Negative pressure wound treatment } \\
\text { Antibiotic treatment as indicated } \\
\text { Na thiosulfate } \\
\text { Skin graft (rather early than late) }\end{array}$ & $\begin{array}{l}\text { Control cardiovascular risk factors } \\
\text { Sufficient analgetics as required } \\
\text { Sodium thiosulfate over many weeks } \\
\text { Antibiotic treatment as indicated } \\
\text { Cautious debridement/necrosectomy/ } \\
\text { 'biobags' with maggots as alternative } \\
\text { (wound surgery more delicate in very } \\
\text { thick fatty layers) } \\
\text { Skin grafts as soon as granulation } \\
\text { appears }\end{array}$ & $\begin{array}{l}\text { Control cardiovascular risk factors } \\
\text { Sufficient analgetics as required } \\
\text { Debridement or necrosectomy } \\
\text { In extensive cases: } \\
\text { Negative pressure wound treatment } \\
\text { Antibiotic treatment as indicated } \\
\text { Na thiosulfate } \\
\text { Skin graft (rather early than late) }\end{array}$ & $\begin{array}{l}\text { Control cardiovascular risk factors } \\
\text { Sufficient analgetics as required } \\
\text { Sodium thiosulfate over many weeks } \\
\text { Antibiotic treatment as indicated } \\
\text { Cautious debridement/necrosectomy/ } \\
\text { 'biobags' with maggots as alternative } \\
\text { (wound surgery more delicate in very } \\
\text { thick fatty layers) } \\
\text { Skin grafts as soon as granulation } \\
\text { appears }\end{array}$ \\
\hline
\end{tabular}

the fascia-like surface which lies behind the Achilles tendon and below the fatty tissue located there. Normal walking is possible even with a resectioned Achilles tendon (fig. 4a-e).

\section{Future Research Directions}

\section{Solid Organ Involvement}

If patients with calciphylaxis or Martorell HYTILU, or their relatives, give informed consent to an autopsy in case of their demise, data on solid organ involvement should be systematically obtained.

\section{Pathophysiology}

Studies in cell biology of tissue and plasma from patients with Martorell HYTILU and calciphylaxis should provide more information regarding the pathogenesis of arteriolosclerosis and the peculiar 'miniaturized' form of medial calcinosis, and thus hopefully enable the development of effective preventive measures or specific medications.

Calciphylaxis and Martorell Leg Ulcer: Same Pathophysiology

\section{The Puzzle of the Typical Location on the}

Laterodorsal Leg

No plausible explanation for the strikingly consistent wound location of Martorell HYTILU on the laterodorsal leg and/or the Achilles tendon has yet been provided. Perhaps the angiosome concept can explain this puzzling specificity.

\section{Conclusion}

In the above paper, we present a closer look at four diseases which are probably closely related to one another pathophysiologically (table 1):
A Calciphylaxis (distal pattern)
B Calciphylaxis (proximal pattern)
C Martorell HYTILU
D Calciphylaxis with normal renal and parathyroid function (eutrophication)

The four diseases have largely the same risk factors: (1) arterial hypertension, (2) diabetes mellitus (types 1 and 2), (3) secondary or tertiary hyperparathyroidism (in 
Table 2. Martorell HYTILU: confounders

\begin{tabular}{|c|c|c|c|}
\hline Martorell HYTILU & Pyoderma gangrenosum & Necrotizing vasculitis & Livedoid vasculopathy \\
\hline $\begin{array}{l}\text { Clinical pattern } \\
\text { Skin infarction } \pm \text { livedo } \\
\text { - Very painful } \\
\text { - Laterodorsal leg } \\
\text { - Achilles tendon } \\
\text { - Other locations (rare) } \\
\text { Cardiovascular risk factors } \\
\text { - Hypertension (100\%) } \\
\text { - Diabetes mellitus type 2 (60\%) }\end{array}$ & $\begin{array}{l}\text { Progressive, initially superficial } \\
\text { breakdown of skin, with violaceous } \\
\text { and pustular border } \\
\text { - Very painful } \\
\text { - Steroid-responsive } \\
\text { Associated conditions } \\
\text { - Inflammatory bowel disease } \\
\text { - Myeloid leukemia } \\
\text { - Other neutrophilic diseases } \\
\text { - Rheumatoid arthritis }\end{array}$ & $\begin{array}{l}\text { Skin infarction } \pm \text { livedo } \\
\text { - Predominantly legs (any aspect) } \\
\text { - Often multiple and symmetric } \\
\text { - Very painful } \\
\text { Associated conditions } \\
\text { - Rheumatoid arthritis } \\
\text { - Systemic lupus erythematosus } \\
\text { - Hepatitis B and C } \\
\text { - Bacterial infections } \\
\text { - ANCA-associated vasculitis } \\
\text { - List nonexhaustive }\end{array}$ & $\begin{array}{l}\text { Livedo and superficial skin ulceration } \\
\text { around malleoli and dorsum of foot } \\
\text { - Usually symmetric } \\
\text { - Leaves atrophic scars } \\
\text { - Very painful } \\
\text { Associated conditions } \\
\text { - Smoking } \\
\text { - Thrombophilia }\end{array}$ \\
\hline $\begin{array}{l}\text { Histopathology } \\
\text { Subcutaneous arteriolosclerosis } \\
\text { - Thick vessel wall } \\
\text { - Narrow vessel lumen } \\
\text { - Arteriolar thrombosis } \\
\text { - Miniaturized Mönckeberg } \\
\quad \text { medial calcinosis }\end{array}$ & $\begin{array}{l}\text { Skin necrosis with dense sheets of } \\
\text { polymorphonuclear leukocytes }\end{array}$ & $\begin{array}{l}\text { Histology depends on subtype of vasculitis: } \\
\text { skin necrosis with } \\
\text { - Leukocytoclastic vasculitis of subcutaneous } \\
\text { plexus } \\
\text { - Panarteritis nodosa } \\
\text { - List nonexhaustive }\end{array}$ & $\begin{array}{l}\text { Hyalinosis and acellular thrombosis of small } \\
\text { vessels of subpapillary plexus } \\
\text { Scarce inflammatory infiltrate }\end{array}$ \\
\hline $\begin{array}{l}\text { Treatment } \\
\text { Control cardiovascular risk factors } \\
\text { Sufficient analgetics as required } \\
\text { Debridement or necrosectomy } \\
\text { In extensive cases: } \\
\text { Negative pressure wound treatment } \\
\text { Antibiotic treatment as indicated } \\
\text { Na thiosulfate } \\
\text { Skin graft (rather early than late) }\end{array}$ & $\begin{array}{l}\text { Systemic immunosuppression } \\
\text { - Glucocorticosteroids } \\
\text { - Calcineurin inhibitors } \\
\text { - TNF- } \alpha \text { inhibitors } \\
\text { Management of associated } \\
\text { conditions }\end{array}$ & $\begin{array}{l}\text { Systemic immunosuppression } \\
\text { - Glucocorticosteroids } \\
\text { - Steroid-sparing agents } \\
\text { Debridement or necrosectomy } \\
\text { In extensive cases: } \\
\text { Negative pressure wound treatment } \\
\text { Antibiotic treatment as indicated } \\
\text { Skin graft (rather early than late) }\end{array}$ & $\begin{array}{l}\text { Anticoagulation (direct factor } \mathrm{X} \text { inhibitors, } \\
\text { e.g. rivaroxaban, or low-molecular-weight } \\
\text { heparins) } \\
\text { Stop smoking } \\
\text { In extensive cases: } \\
\text { Antibiotic treatment as indicated } \\
\text { Skin graft (rather early than late) }\end{array}$ \\
\hline
\end{tabular}

end-stage kidney disease) and (4) oral anticoagulation with vitamin $\mathrm{K}$ antagonists.

They share the same clinical patterns: necrotizing livedo, skin infarctions at typical locations and acral gangrene in calciphylaxis.

They also share the same histopathology: ischemic subcutaneous arteriolosclerosis and small-artery disease and 'miniaturizing' Mönckeberg medial calcinosis.

The treatment concept for the acute phase of the diseases is also broadly similar. In addition to optimized control of the cardiovascular risk factors, a proactive wound approach (necrosectomy, negative pressure wound treatment, and early skin grafts supported by systemic antibiotic therapy) leads most rapidly and effectively to a reduction of the initially severe wound pain, and finally to complete healing of the wound.

Oral anticoagulation with vitamin $\mathrm{K}$ antagonists should be stopped. In extensive cases, the use of intravenous sodium thiosulfate is recommended.

All four diagnoses are little known in the medical schools of most countries. The need to improve familiarity with these four closely related disorders is therefore great. In particular, the risk of confusion with pyoderma gangrenosum is a major diagnostic problem which can lead to false and even damaging treatment (table 2). Al- though atherosclerosis of the large and medium blood vessels, e.g. the coronary arteries, the carotid arteries etc., and microangiopathy of the capillaries, e.g. in collagen vascular diseases, are well researched, arteriolosclerosis is to this day largely underresearched. It is possible that cardiological, cerebral, renal and other vascular diseases are more frequently determined by arteriolosclerotic processes than we are currently aware. The subcutaneous arterioles are relatively easily accessible for research. The concept of subcutaneous arteriolosclerosis and the four corresponding diagnoses could therefore play a relevant role in clarifying these pathologies in the future.

\section{Statement of Ethics}

This review is based on clinical and histopathology data that were collected during two clinical studies (Hafner et al. [7] and NCT 01578382). All included patients gave written informed consent to the use of clinical data and histology slides.

\section{Disclosure Statement}

The author declares that he has no conflict of interest. 


\section{References}

1 Llach F: Calcific uremic arteriolopathy (calciphylaxis): an evolving entity? Am J Kidney Dis 1998;32:514-518.

2 Coates T, Kirkland GS, Dymock RB, Murphy BF, Brealey JK, Mathew TH, Disney AP: Cutaneous necrosis from calcific uremic arteriolopathy. Am J Kidney Dis 1998;32:384-391.

3 Hafner J, Keusch G, Wahl C, Burg G: Calciphylaxis: a syndrome of skin necrosis and acral gangrene in chronic renal failure. Vasa 1998;27:137-143.

4 Brandenburg VM, Kramann $\mathrm{R}$, Rothe $\mathrm{H}$, Kaesler N, Korbiel J, Specht P, Schmitz S, Krüger T, Floege J, Ketteler M: Calcific uraemic arteriolopathy (calciphylaxis): data from a large nationwide registry. Nephrol Dial Transplant 2016, Epub ahead of print.

5 Selye H: Calciphylaxis. Chicago, University of Chicago Press, 1962.

6 Hafner J, Keusch G, Wahl C, Sauter B, Hürlimann A, von Weizsäcker F, Krayenbühl M, Biedermann K, Brunner U, Helfenstein U: Uremic small-artery disease with medial calcification and intimal hyperplasia (so-called calciphylaxis): a complication of chronic renal failure and benefit from parathyroidectomy. J Am Acad Dermatol 1995;33:954-962.

7 Hafner J, Nobbe S, Partsch H, Läuchli S, Mayer D, Amann-Vesti B, Speich R, Schmid C, Burg G, French LE: Martorell hypertensive ischemic leg ulcer: a model of ischemic subcutaneous arteriolosclerosis. Arch Dermatol 2010;146:961-968.

8 Vuerstaek JD, Reeder SW, Henquet CJ, Neumann HA: Arteriolosclerotic ulcer of Martorell. J Eur Acad Dermatol Venereol 2010;24 867-874.
9 Lozano FS, Cabot X, Silva I, Roche E, Callejas JM: Fernando Martorell (1906-1984): centenary of a pioneer in angiology. Angiology 2008;59:98-99.

10 Martorell F: Las ulceras supramaleolares por arteriolitis de las grandes hipertensas. Actas (Reun Cientif Cuerpo Facul) Inst Policlinico Barcelona 1945;1:6-9.

11 Hines EA Jr, Farber EM. Ulcer of the leg due to arteriolosclerosis and ischemia, occurring in the presence of hypertensive disease (hypertensive-ischemic ulcers): a preliminary report. Proc Staff Meet Mayo Clin 1946;21:337346.

12 Farber EM, Hines EA Jr, Montgomery $\mathrm{H}$, Craig W. The arterioles of the skin in essential hypertension. J Invest Dermatol 1947;9:285298.

13 Schnier BR, Sheps SG, Juergens JL. Hypertensive ischemic ulcer: a review of 40 cases. Am J Cardiol 1966;17:560-565.

14 Bertranou EG, Gonoraky SE, Otero AE: Ulcère arteriolaire hypertensive de Martorell: résultat de traitement ambulatoire sur 366 cas. Phlébologie 2001;54:267-272.

15 Lazareth I, Priollet P: Necrotic angiodermatitis: treatment by early cutaneous grafts (in French). Ann Dermatol Vénéréol 1995;122. 575-578.

16 Dagregorio G, Guillet G: A retrospective review of 20 hypertensive leg ulcers treated with mesh skin grafts. J Eur Acad Dermatol Venereol 2006;20:166-169.
17 Kalajian AH, Malhotra PS, Callen JP, Parker LP: Calciphylaxis with normal renal and parathyroid function: not as rare as previously believed. Arch Dermatol 2009;145:451-458.

18 Ramsey-Stewart G: Eutrophication: spontaneous progressive dermatoliponecrosis. A fatal complication of gross morbid obesity. Obes Surg 1992;2:263-264.

19 Hackett BC, McAleer MA, Sheehan G, Powell FC, O'Donnell BF: Calciphylaxis in a patient with normal renal function: response to treatment with sodium thiosulfate. Clin Exp Dermatol 2009;34:39-42.

20 Schafer C, Heiss A, Schwarz A, Westenfeld R, Ketteler M, Floege J, Muller-Esterl W, Schinke T, Jahnen-Dechent W: The serum protein alpha 2-Heremans-Schmid glycoprotein/fetuin-A is a systemically acting inhibitor of ectopic calcification. J Clin Invest 2003;112: 357-366.

21 Galloway PA, El-Damanawi R, Bardsley V, Pritchard NR, Fry AC, Ojha SK, Hiemstra TF: Vitamin $\mathrm{K}$ antagonists predispose to calciphylaxis in patients with end-stage renal disease. Nephron 2015;129:197-201.

22 Nigwekar SU, Kroshinsky D, Nazarian RM, Goverman J, Malhotra R, Jackson VA, Kamdar MM, Steele DJ, Thadhani RI: Calciphylaxis: risk factors, diagnosis, and treatment. Am J Kidney Dis 2015;66:133-146.

23 Körber A, Klode J, Al-Benna S, Wax C, Schadendorf D, Steinstraesser L, Dissemond J: Etiology of chronic leg ulcers in 31,619 patients in Germany analyzed by an expert survey. J Dtsch Dermatol Ges 2011;9:116-121. 